\title{
Synthesis and Acid-Base Properties of Tetraphenylporphine Derivatives with Amino Acid "Anchor" Groups
}

\author{
Yu. B. Ivanova ${ }^{a} *$, S. G. Pukhovskaya ${ }^{b}$, T. V. Shorokhova ${ }^{b}$, Yu. V. Khrushkova ${ }^{b}$, \\ A. O. Plotnikova ${ }^{b}$, A. V. Lyubimtsev ${ }^{b}$, and S. A. Syrbu ${ }^{a}$ \\ ${ }^{a}$ G.A. Krestov Institute of Solution Chemistry of the Russian Academy of Sciences, Ivanovo, 153045 Russia \\ ${ }^{b}$ Ivanovo State University of Chemistry and Technology, Ivanovo, 153000 Russia \\ *e-mail: jjiv@yandex.ru
}

Received March 24, 2021; revised March 24, 2021; accepted April 8, 2021

\begin{abstract}
Asymmetrically substituted 5,10,15,20-tetraphenylporphyrin derivatives such as 5-(4-aminophenyl)10,15,20-triphenylporphine, 5-[4-(tyrosinylamino)phenyl]-10,15,20-triphenylporphine and 5-\{4-[(N-tertbutoxycarbonyltyrosinyl)amino]phenyl $\}-10,15,20$-triphenylporphine were synthesized. Their spectral and acidbase properties were studied. The acid-base interactions of the obtained compounds in the binary acetonitrileperchloric acid and dimethyl sulfoxide-potassium cryptate (KOH[222]) systems were studied by spectrophotometry method. The effect of the nature of the solvent, concentration, $\mathrm{pH}$ value on the chemical activity of porphyrin was analyzed. Amino acid fragments affect the protolytic equilibrium of porphyrins in acidic and basic media.
\end{abstract}

Keywords: porphyrins, amino acid groups, acid-base equilibria

DOI: $10.1134 / \mathrm{S} 1070363221050078$

Porphyrins are widespread in nature and play an important role in natural biochemical and biophysical processes [1]. With their help, the most important biological, photochemical and enzymatic reactions are occurred in nature [2]. Some synthetic porphyrins can be used as starting compounds for the obtaining of biologically active substances [3], and a number of representatives of this class are used or have application perspectives in medicine as photosensitizers for photodynamic therapy of oncological diseases, as well as antimicrobial drugs and agents for viruses inactivating [4-6], which is especially important in the fight against the coronavirus epidemic.

The introduction of substituents of different natures makes it possible to vary the physicochemical properties of porphyrins in a wide range $[7,8]$. The conjugates synthesis with various biomolecules, including amino acids, leads to compounds with a number of unique photophysical and biochemical properties [9]. Such conjugates can participate in the formation of S1-macroheterocycle-S2 bridging structures and effectively participate in virus inactivation [10]. To identify the patterns of structureactivity of a macroheterocyclic molecule, it is necessary to study a number of fundamental properties of conjugates, in particular, acid-base properties.

Using the spectrophotometric method, it is possible to obtain a qualitative and quantitative characteristic of the acid-base equilibrium, to determine the influence of the solvent nature, the porphyrin concentration, the presence of extraneous ions, and the medium $\mathrm{pH}$. The availability of the spectrophotometric method is an important advantage that allow accumulate a rather large amount of information in this direction, to study many structural states of a macromolecule and its conformational rearrangements under the action of a number of physicochemical factors in real time. The recorded change in the spectral properties of a macromolecule carries with it important information not only about its state, but also about the nature of the chromophores microenvironment.

The most widely available and studied synthetic porphyrin-5,10,15,20-tetraphenylporphine $\left(\mathbf{H}_{\mathbf{2}} \mathbf{T P P}\right)$ is a convenient object for further modification of its periphery. We obtained derivatives of asymmetrically substituted 5,10,15,20-tetraphenylporphyrin and investigated their spectral, acid-base properties. For comparison, 


\section{Scheme 1.}

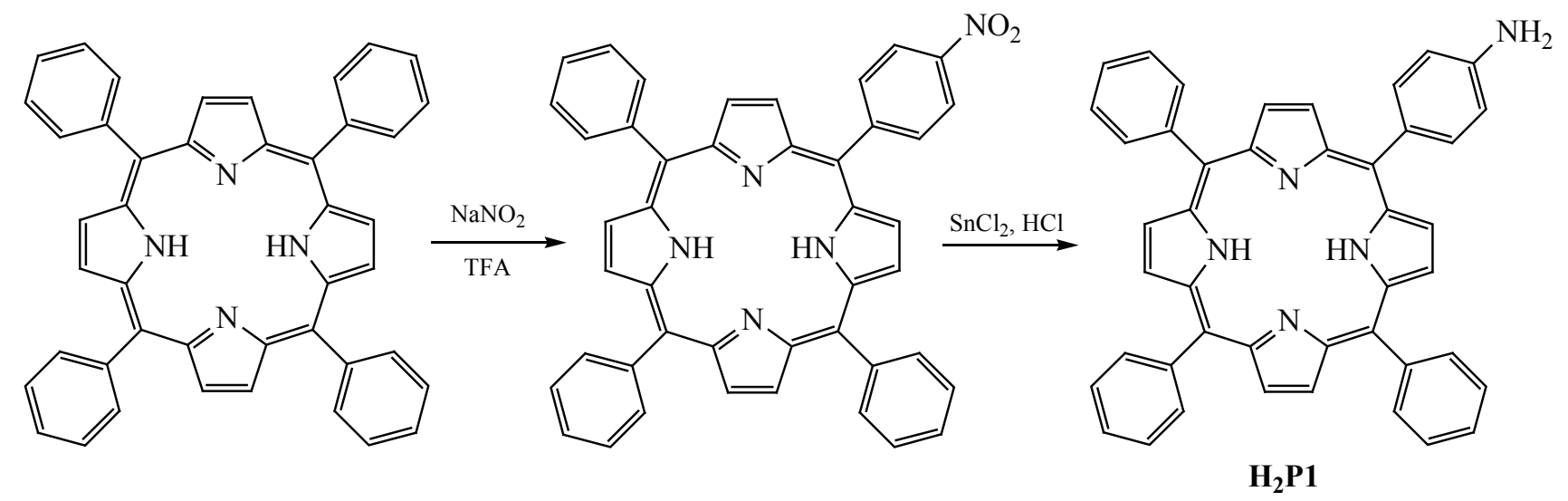

5-(4-aminophenyl)-10,15,20-triphenylporphine $\mathbf{H}_{2} \mathbf{P} \mathbf{1}$ was used. 5-[4-(Tyrosinylamino)phenyl]-10,15,20triphenylporphine $\mathbf{H}_{2} \mathbf{P} 2$ and 5- $\{4-[(N$-tert-butoxycarbonyltyrosinyl)amino]phenyl $\}$-10,15,20-triphenylporphine $\mathbf{H}_{2} \mathbf{P 3}$ were synthesized by introducing substituents into para-position of one of the phenyl fragment.

The synthesis of asymmetrically substituted porphyrins involves several steps. Aminophenylporphyrins are practically impossible to obtain by direct condensation of aminobenzaldehyde with pyrrole, since the starting aminobenzaldehydes are very unstable. Because of this, unsymmetrical $p$-aminophenylporphyrins are usually synthesized by reduction of the corresponding $p$-nitrophenylporphyrins, which are obtained in rather high yields by regioselective nitration of tetraphenylporphine with an equimolar amount of sodium nitrite in trifluoroacetic acid (TFA, Scheme 1).

5-(4-Nitropheny1)-10,15,20-triphenylporphine was reduced with $\mathrm{SnCl}_{2}$ in $\mathrm{HCl}$ to produce 4-aminophenylporphyrin $\mathbf{H}_{\mathbf{2}} \mathbf{P} \mathbf{1}$ [11]. $\{4-[N$-(tert-Butoxycarbonyl)tyrosinyl]amino phenylporphyrin $\mathbf{H}_{\mathbf{2}} \mathbf{P} \mathbf{3}$ was obtained by acylation of 5-(4-aminophenyl)-10,15,20triphenylporphine $\mathbf{H}_{\mathbf{2}} \mathbf{P} \mathbf{1}$ with Boc-tyrosine in the presence of 1-(3-dimethylaminopropyl)-3-ethylcarbodiimide hydrochloride (EDC) and 4-dimethylaminopyridine (DMAP) in methylene chloride at room temperature (Scheme 2).

The Boc-protection was removed in the presence of trifluoroacetic acid in dichloromethane at room temperature for $4 \mathrm{~h}$ to obtain the compound $\mathbf{H}_{2} \mathbf{P 2}$. The reaction completion was monitored by TLC.
As a result of the structural modification of the molecule, the electronic effects of substituents lead to a redistribution of the electron density between the macrocycle and the added fragments, which affects the acid-base properties of the compound as a whole. The concept of acid-base properties of tetrapyrrole macrocycles includes the formation of anionic and cationic forms of an acid-base nature, proceeding with a charge change due to proton exchange in alkaline or acidic media. Porphyrins can be seen as typical amphoteric compounds with both basic (N-bases) and very weak acidic (NH-acids) properties. Depending on the medium $\mathrm{pH}$, it is possible to obtain both singly- and doubly charged ions, which are in equilibrium with each other and with a neutral form [Eqs. (1)-(4)] [12].

$$
\begin{gathered}
\mathrm{H}_{3} \mathrm{P}^{+} \stackrel{K_{b 1}}{\rightleftarrows} \mathrm{H}_{2} \mathrm{P}+\mathrm{H}^{+}, \\
\mathrm{H}_{4} \mathrm{P}^{2+} \stackrel{K_{b 2}}{\rightleftarrows} \mathrm{H}_{3} \mathrm{P}^{+}+\mathrm{H}^{+}, \\
\mathrm{H}_{2} \mathrm{P} \stackrel{K_{a 1}}{\rightleftarrows} \mathrm{HP}^{-}+\mathrm{H}^{+}, \\
\mathrm{HP}^{2-} \stackrel{K_{a 2}}{\rightleftarrows} \mathrm{P}^{2-}+\mathrm{H}^{+} .
\end{gathered}
$$

Here $\mathrm{H}_{2} \mathrm{P}, \mathrm{H}_{3} \mathrm{P}^{+}, \mathrm{H}_{4} \mathrm{P}^{2+}, \mathrm{HP}^{-}$, and $\mathrm{P}^{2-}$ are free base, mono-, and doubly protonated and deprotonated porphyrins forms $\mathrm{H}_{2} \mathrm{P} 1, \mathrm{H}_{2} \mathrm{P} 2, \mathrm{H}_{2} \mathrm{P}$, respectively.

The acid-base properties of porphyrins $\mathbf{H}_{2} \mathbf{P 1}, \mathbf{H}_{2} \mathbf{P}$, $\mathbf{H}_{2} \mathbf{P 3}$ were investigated in both acidic and alkaline media in systems acetonitrile-perchloric acid ( $0.01 \mathrm{M}$ solution in acetonitrile) and dimethyl sulfoxide-potassium cryptate $(\mathrm{KOH}[222])(0.01 \mathrm{M}$ solution) at $298 \mathrm{~K}$. Solution 
Scheme 2.
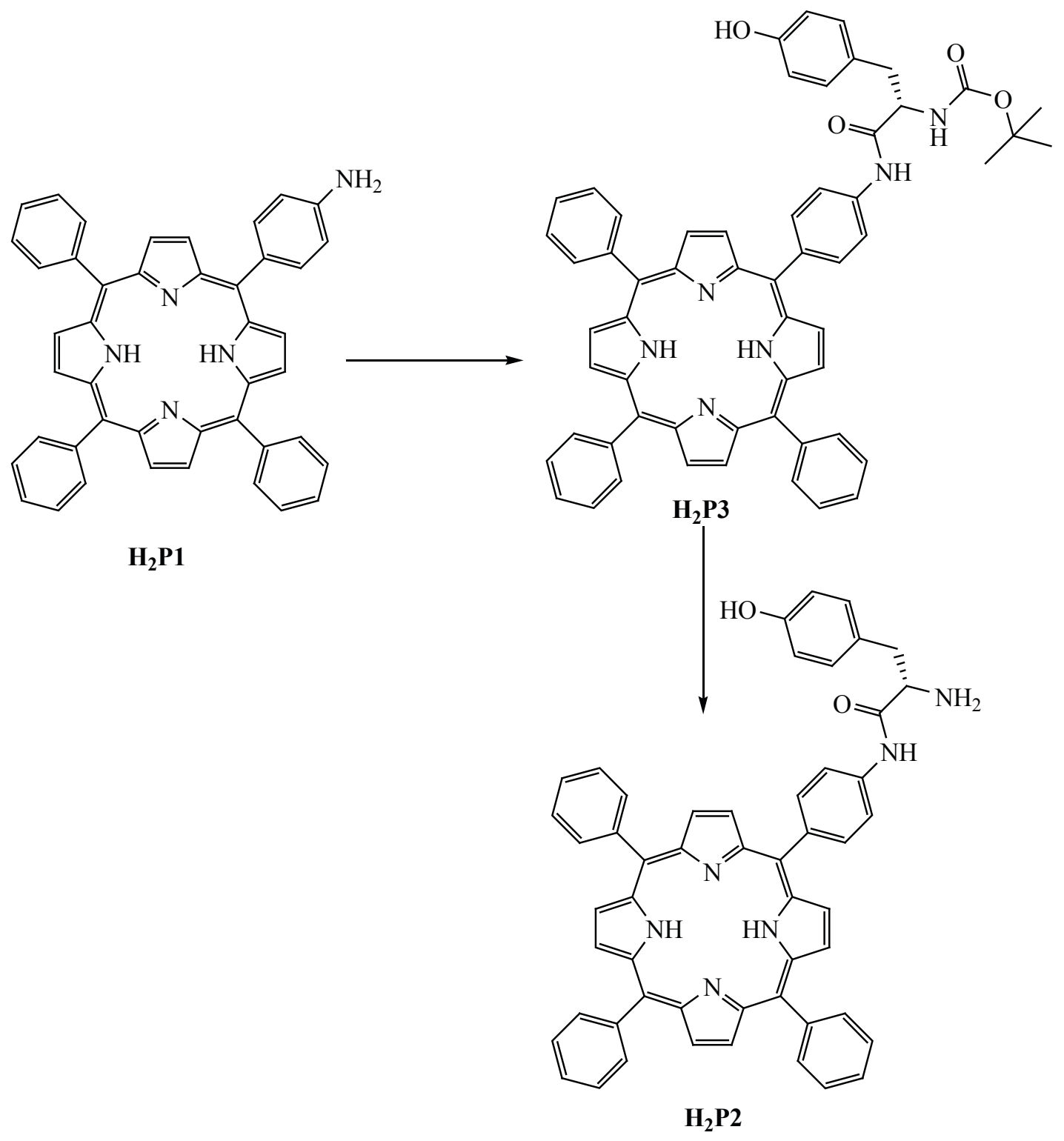

$\mathrm{KOH}[222]$ [13] was obtained by dissolution $\mathrm{KOH}$ prills in DMSO in the presence of 4,7,13,16,21,24-hexaoxa-1,10diazabicyclo[8.8.8] hexacosane (cryptand[222]). Under these conditions, $\mathrm{HClO}_{4}$, which has a high dissociation constant in acetonitrile [14], is completely dissociated, and protonation proceeds due to the solvated proton.

The total base ionization constant for the studied compounds in the acetonitrile- $\mathrm{HClO}_{4}$ system at $298 \mathrm{~K}$ was calculated using Eq. (5) [12].

$$
\mathrm{p} K_{b}=\mathrm{pH}+\log \text { Ind } .
$$

Here $K_{b}-\mathrm{K}_{b 1}, \mathrm{~K}_{b 2}, \mathrm{~K}_{b 1,2}$-the first, second, or first and second steps of the protonation constants, Ind-indicator

ratio $\left[\mathrm{H}_{2} \mathrm{P}\right] /\left[\mathrm{H}_{3} \mathrm{P}^{+}\right]$or $\left[\mathrm{H}_{3} \mathrm{P}^{+}\right] /\left[\mathrm{H}_{4} \mathrm{P}^{2+}\right],\left[\mathrm{H}_{2} \mathrm{P}\right] /\left[\mathrm{H}_{4} \mathrm{P}^{2+}\right]$, $\mathrm{pH}$ is the analytical acidity of the solution created by the titrant, found using the data obtained earlier from the spectrophoto- and potentiometric $\mathrm{pH}$-function analysis of a glass electrode [15].

The total acid dissociation constant of the studied compounds in the (KOH[222])-DMSO system at $298 \mathrm{~K}$ was calculated using Eq. (6) [12].

$$
\mathrm{p} K_{a}=\log \text { Ind }+\log c_{\mathrm{KOH}[222]} .
$$

Here $K_{a}-K_{a 1}, K_{a 2} K_{a 1,2}$-the first, second, or for the first and second steps of the deprotonation constants, Indindicator ratio $\left[\mathrm{HP}^{-}\right] /\left[\mathrm{H}_{2} \mathrm{P}\right],\left[\mathrm{P}^{2-}\right] /\left[\mathrm{H}_{2} \mathrm{P}^{2}\right]$ or $\left[\mathrm{P}^{2-}\right] /\left[\mathrm{H}_{2} \mathrm{P}\right]$, 


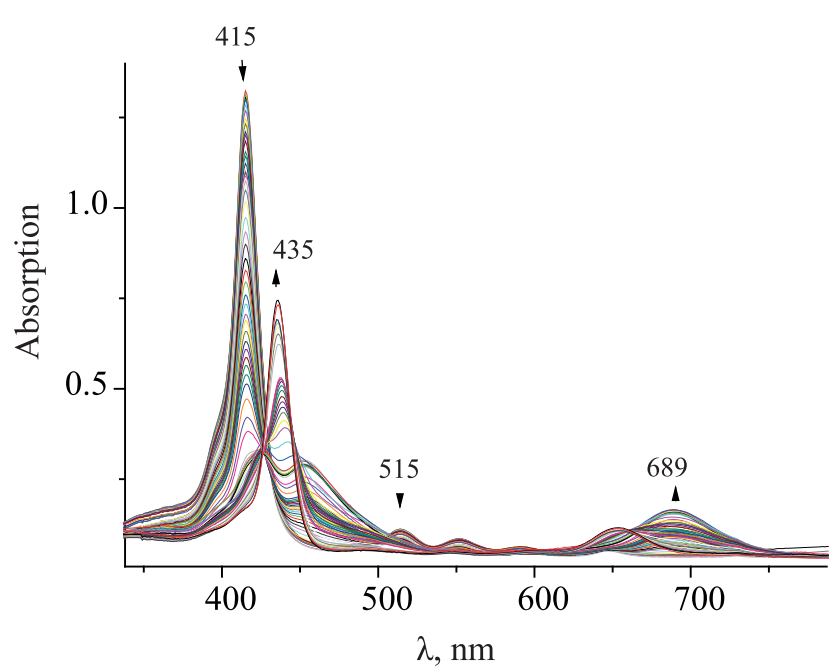

Fig. 1. Change in the electronic absorption spectrum of compound $\mathbf{H}_{2} \mathbf{P 1}$ in acetonitrile- $\mathrm{HClO}_{4}$ system, $\left(\left[\mathbf{H}_{2} \mathbf{P 1}\right]=\right.$ $\left.1.21 \times 10^{-5} \mathrm{~mol} / \mathrm{L},\left[\mathrm{HClO}_{4}\right]=0-1.51 \times 10^{-4} \mathrm{~mol} / \mathrm{L}\right)$ at $298 \mathrm{~K}$.

$\log c_{\mathrm{KOH}[222]}$-analytical concentration of the titrant $\mathrm{KOH}[222]$ in DMSO. These data were used to calculate the deprotonation constants. The error in the constants measuring did not exceed $3-5 \%$.

In examining the base properties of $\mathbf{H}_{\mathbf{2}} \mathbf{P} \mathbf{1}, \mathbf{H}_{\mathbf{2}} \mathbf{P} \mathbf{2}$, $\mathbf{H}_{\mathbf{2}} \mathbf{P 3}$ (Figs. 1-3) and analyzing changes in the electron absorption spectra, as well as spectrophotometric titration curves of porphyrins, several families of isobestic points were found, each of which corresponded to its own family of spectral curves and its own section on the titration curves. For compounds $\mathbf{H}_{2} \mathbf{P} 1$ and $\mathbf{H}_{2} \mathbf{P} 2$, three regions have been distinguished, showing that, possibly, at first protonation proceeds through the nitrogen atoms of the substituent $\left(\mathrm{p} K_{b} 13.36\right.$ and 13.34 for $\mathbf{H}_{\mathbf{2}} \mathbf{P} \mathbf{1}$ and $\mathbf{H}_{\mathbf{2}} \mathbf{P} 2$, respectively) and only then sequentially through the intracyclic nitrogen atoms in two steps. The parameters of the electron absorption spectra of ionized and neutral forms of porphyrins, as well as stepwise ionization constants, are given in Table 1.

The dependences of the indicator ratio on $\log c_{\mathrm{HClO}_{4}}$ at the protonation steps are straightforward; the slope of the straight lines is close to 1 , which confirms our assumptions about the sequential addition of one proton at each stage of protonation.

In examining the base properties of the compound $\mathbf{H}_{2} \mathbf{P 3}$ (Fig. 4, Table 1) and analyzing changes in the electron absorption spectra and the titration curve, two

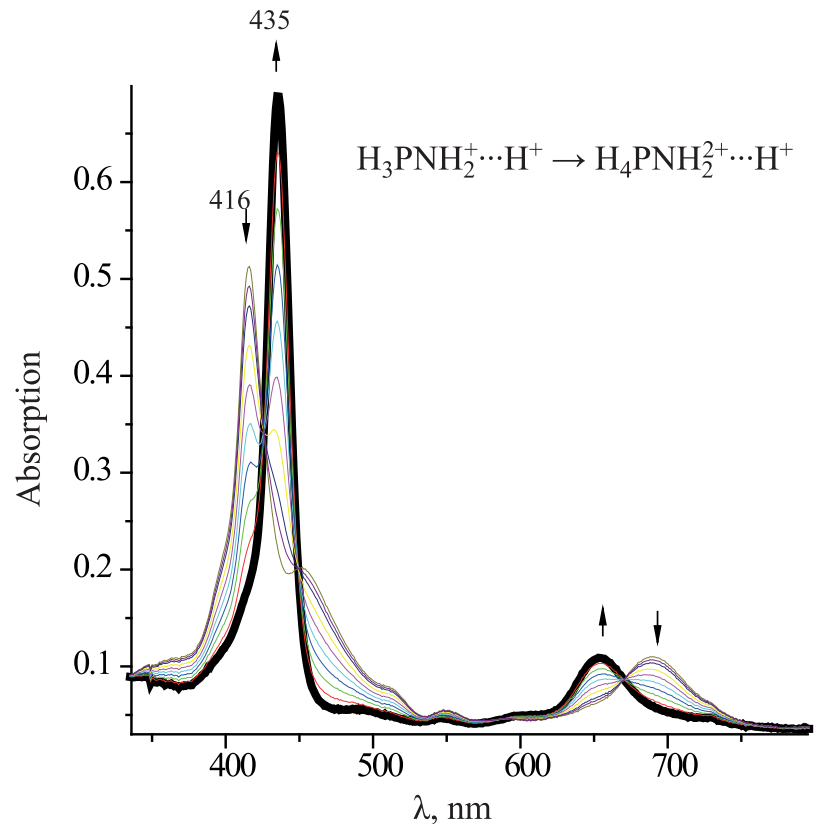

Fig. 2. Change in the electronic absorption spectrum in $\mathbf{H}_{2} \mathbf{P 1}-$ acetonitrile- $\mathrm{HClO}_{4}$ system $\left(\left[\mathrm{HClO}_{4}\right]=7.94 \times 10^{-6}-1.25 \times\right.$ $\left.10^{-5} \mathrm{~mol} / \mathrm{L}\right)$.

families of spectral curves and two steps in the titration curves were revealed. Consequently, protonation occurs in two steps. The nature of the changes in the electron absorption spectra suggests that protonation occurs along the central nitrogen atoms of the macrocycle. The dependence of the indicator ratio on the logarithm of the perchloric acid concentration in steps also corresponds to two-steps protonation.

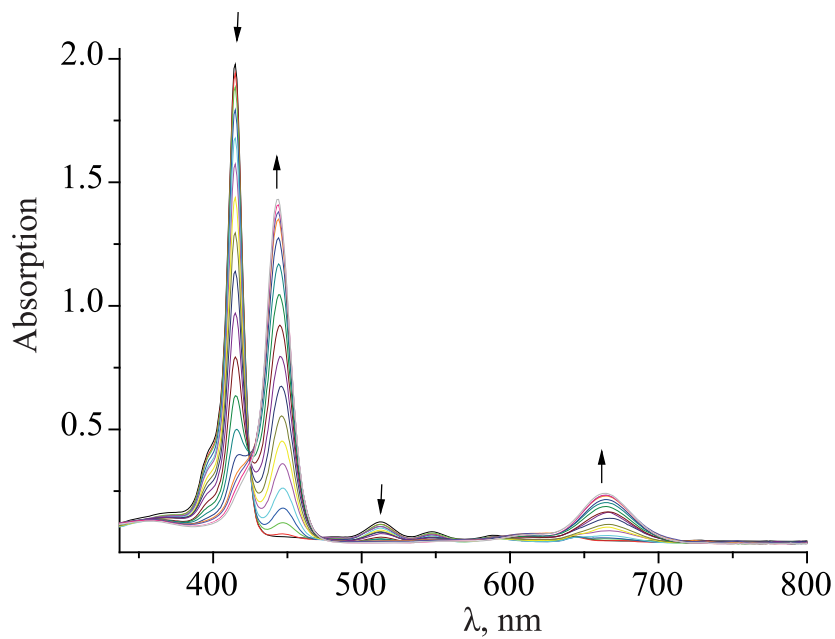

Fig. 3. Change in the electronic absorption spectrum in the $\mathbf{H}_{2} \mathbf{P} 2$-acetonitrile- $\mathrm{HClO}_{4}$ system $\left(\left[\mathrm{HClO}_{4}\right]=0-1.54 \times\right.$ $\left.10^{-5} \mathrm{~mol} / \mathrm{L}\right)$. 
Table 1. Parameters of electron absorption spectra of porphyrins $\mathbf{H}_{2} \mathbf{P 1}, \mathbf{H}_{2} \mathbf{P} 2, \mathbf{H}_{2} \mathbf{P 3}$ and their ionized forms, acidity and basicity constants in DMSO and acetonitrile

\begin{tabular}{|c|c|c|c|c|c|c|c|c|c|}
\hline \multirow{2}{*}{$\begin{array}{c}\text { Porphyrin } \\
\mathbf{H}_{2} \mathbf{P 1}\end{array}$} & \multicolumn{5}{|c|}{$\lambda(\log \varepsilon)$} & \multirow{2}{*}{$\begin{array}{l}\mathrm{p} K_{b 1} \\
11.50\end{array}$} & \multirow{2}{*}{$\begin{array}{l}\mathrm{p} K_{b 1} \\
9.65\end{array}$} & \multirow{2}{*}{$\frac{\sum \mathrm{p} K_{b 1,2}}{21.15}$} & \multirow{2}{*}{$\frac{\sum \mathrm{p} K_{a 1,2}}{6.90}$} \\
\hline & $415(5.03)^{\mathrm{a}}$ & $514(3.95)$ & $590(3.70)$ & $648(2.90)$ & $552(3.83)$ & & & & \\
\hline & $420(4.88)^{b}$ & $517(4.10)$ & $558(3.98)$ & $\begin{array}{l}594 \text { br (3.75) } \\
654(3.82)\end{array}$ & $736(3.65)$ & & & & \\
\hline $\mathbf{H}_{3} \mathbf{P}^{+} \mathbf{1}$ & $416(4.64)^{\mathrm{a}}$ & $453(4.21)$ & - & $689(3.96)$ & & & & & \\
\hline $\mathbf{H}_{4} \mathbf{P}^{2+} \mathbf{1}$ & $435(4.75)^{\mathrm{a}}$ & & $548(3.95)$ & 654 (3.55) & & & & & \\
\hline $\mathbf{P}^{2-1}$ & $447(4.89)^{\mathrm{b}}$ & & $598(3.80)$ & $643(3.86)$ & & & & & \\
\hline $\mathrm{H}_{2} \mathrm{P} 2$ & $415(5.05)^{\mathrm{a}}$ & $513(3.89)$ & $548(3.72)$ & $588(3.65)$ & $645(3.63)$ & 11.24 & 10.92 & 22.16 & 6.4 \\
\hline & $420(5.38)^{\mathrm{b}}$ & $515(4.17)$ & $551(3.90)$ & $590(3.63)$ & $646(3.66)$ & & & & \\
\hline $\mathrm{H}_{3} \mathrm{P}^{+} \mathbf{2}$ & $415(4.94)^{\mathrm{a}}$ & $446(4.57)$ & $513(3.77)$ & - & $666(3.89)$ & & & & \\
\hline $\mathbf{H}_{4} \mathbf{P}^{2+} 2$ & $\begin{array}{l}420 \mathrm{br} \\
(4.30)^{\mathrm{a}}\end{array}$ & 444 (4.98) & - & - & $665(4.21)$ & & & & \\
\hline $\mathbf{P}^{2-2}$ & $447(5.32)^{b}$ & 425 br (4.55) & $595(3.82)$ & - & 641 (3.97) & & & & \\
\hline $\mathrm{H}_{2} \mathrm{P3}$ & $415(5.06)^{\mathrm{a}}$ & $513(3.95)$ & $548(3.82)$ & $591(3.75)$ & $645(3.74)$ & 11.96 & 10.69 & 22.65 & 6.2 \\
\hline & $420(5.40)^{\mathrm{b}}$ & $514(4.24)$ & $552(4.11)$ & 591(4.02) & $646(4.05)$ & & & & \\
\hline $\mathbf{H}_{3} \mathbf{P}^{+} 3$ & $415(4.94)^{\mathrm{a}}$ & 448 (3.98) & $512(3.91)$ & $548(3.81)$ & $590(3.78)$ & & & & \\
\hline $\mathrm{H}_{4} \mathrm{P}^{2+} \mathbf{3}$ & $\begin{array}{l}420 \mathrm{br} \\
(4.16)^{\mathrm{a}}\end{array}$ & $448(4.79)$ & - & - & $670(4.15)$ & & & & \\
\hline $\mathbf{P}^{2-3}$ & $445(5.26)^{\mathrm{b}}$ & - & $593(4.25)$ & - & $639(4.36)$ & & & & \\
\hline
\end{tabular}

${ }^{\text {a }}$ Spectra are recorded in acetonitrile.

${ }^{\mathrm{b}}$ Spectra are recorded in DMSO.

The asymmetry of the porphyrin molecule structure contributes to the stabilization of protonated forms, which makes it possible to isolate and spectrally characterize the forms $\mathrm{H}_{3} \mathrm{P}^{+}$and $\mathrm{H}_{4} \mathrm{P}^{2+}$ for each porphyrin. The base properties of asymmetrically substituted tetraphenylporphins increase in the series of compounds $\mathbf{H}_{2} \mathbf{P 1}<\mathbf{H}_{2} \mathbf{P} 2<\mathbf{H}_{2} \mathbf{P} 3$ by 1.5 orders of magnitude (Table 1 ), which is due to the electronic effect of protonated forms of substituents at the macrocycle periphery. The protonated amino group in compound $\mathbf{H}_{\mathbf{2}} \mathbf{P} \mathbf{1}$ lowers the electron density on the pyrrolenine nitrogen atoms due to the negative induction effect, which leads to a weakening of the nitrogen-hydrogen interaction and to a weakening of the base properties. A weak acid site in the tyrosine group (as in the cysteine group) is capable to ionization at high $\mathrm{pH}$ values [16]. This is probably why the total protonation constants of compounds $\mathbf{H}_{\mathbf{2}} \mathbf{P} \mathbf{1}$ and $\mathbf{H}_{\mathbf{2}} \mathbf{P 2}$ differ. In the examined range of concentrations and $\mathrm{pH}$, protonated peripheral amino groups have a greater effect on the charge of intracyclic nitrogen atoms than tyrosine ones.

The weak acidity of the porphyrins is explained by the relatively high covalence part of the $\mathrm{N}-\mathrm{H}$ bonds. The acid dissociation constants given in [12] were obtained as a result of studying the porphyrins dissociation at the first step, although in some cases $\mathrm{p} K$ refer to processes complicated by the equilibrium of ion pair formation [17].

As shown by spectrophotometric analyses of compounds $\mathbf{H}_{\mathbf{2}} \mathbf{P 1}, \mathbf{H}_{\mathbf{2}} \mathbf{P} 2, \mathbf{H}_{2} \mathbf{P} 3$ in the $\mathrm{KOH}[222]-\mathrm{DMSO}$ system, two families of spectral curves are observed

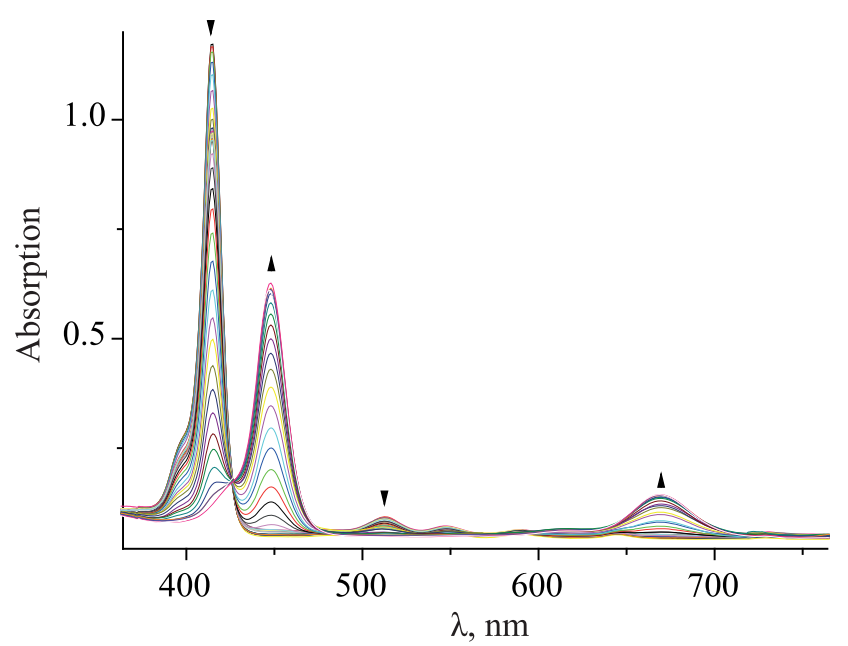

Fig. 4. Change in the electronic absorption spectrum and spectrophotometric titration curve $(\lambda=415 \mathrm{~nm})$ of compound $\mathbf{H}_{2} \mathbf{P 3}$ in acetonitrile $-\mathrm{HClO}_{4}$ system $\left(\left[\mathrm{HClO}_{4}\right]=0-1.51 \times\right.$ $10^{-4} \mathrm{~mol} / \mathrm{L}$ ). 


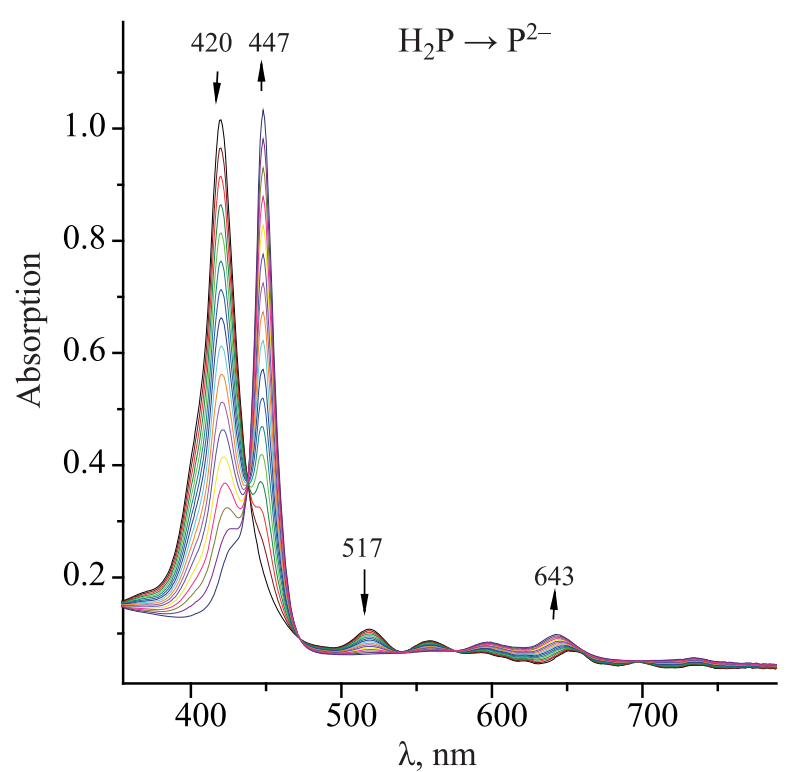

Fig. 5. Change the electronic absorption spectrum of compound $\mathbf{H}_{\mathbf{2}} \mathbf{P 1}$ in DMSO-KOH[222] system $\left(c_{\text {porph }}=\right.$ $\left.1.34 \times 10^{-5} \mathrm{~mol} / \mathrm{L}, c_{\mathrm{KOH}[222]}=0-3.16 \times 10^{-3} \mathrm{~mol} / \mathrm{L}\right)$ at $298 \mathrm{~K}$.

in the electron spectra with an increasing $\mathrm{KOH}[222]$ concentration, each of which corresponds to its own set of isobestic points: at 436, 471, 659 and 439, 473, $662 \mathrm{~nm}\left(\mathbf{H}_{\mathbf{2}} \mathbf{P 1}\right), 385,431,498$ and 387, 434, $502 \mathrm{~nm}$ $\left(\mathbf{H}_{\mathbf{2}} \mathbf{P 2}\right), 385,430,536$ and 387, 433, $538 \mathrm{~nm}\left(\mathbf{H}_{\mathbf{2}} \mathbf{P 3}\right)$ (Figs. 5-7). These data demonstrate a two-steps dissociation of protonated forms. However, the spectrophotometric titration curves constructed on the basis of experimental data do not have pronounced steps, which is possible with stepwise deprotonation with close values of the constants of each equilibrium. The isobestic points and nature of the change in the absorption spectra indicate that, with changing the concentrations of the two absorbing centers of the porphyrin molecule, the ratio between the ionized forms is not violated during deprotonation. The straight-line correlation of the indicator ratio on $\log c_{\mathrm{KOH}[222]}(\tan \alpha \approx 2)$ illustrates two protons elimination from one macromolecule. Parameters of the electron absorption spectra of molecular and doubly deprotonated forms and the acidity constant $\left(\mathrm{p} K_{\mathrm{a} 1.2}\right)$ in the $\mathrm{KOH}[222]-\mathrm{DMSO}$ system for porphyrins $\mathbf{H}_{\mathbf{2}} \mathbf{P 1}, \mathbf{H}_{\mathbf{2}} \mathbf{P}$, $\mathbf{H}_{2} \mathbf{P 3}$ are given in the table. The deprotonation constants in the series of compounds $\mathbf{H}_{2} \mathbf{P} 1, \mathbf{H}_{2} \mathbf{P} 2, \mathbf{H}_{2} \mathbf{P} 3$ in the DMSO-KOH[222] system consistently decrease by less than one order of magnitude.

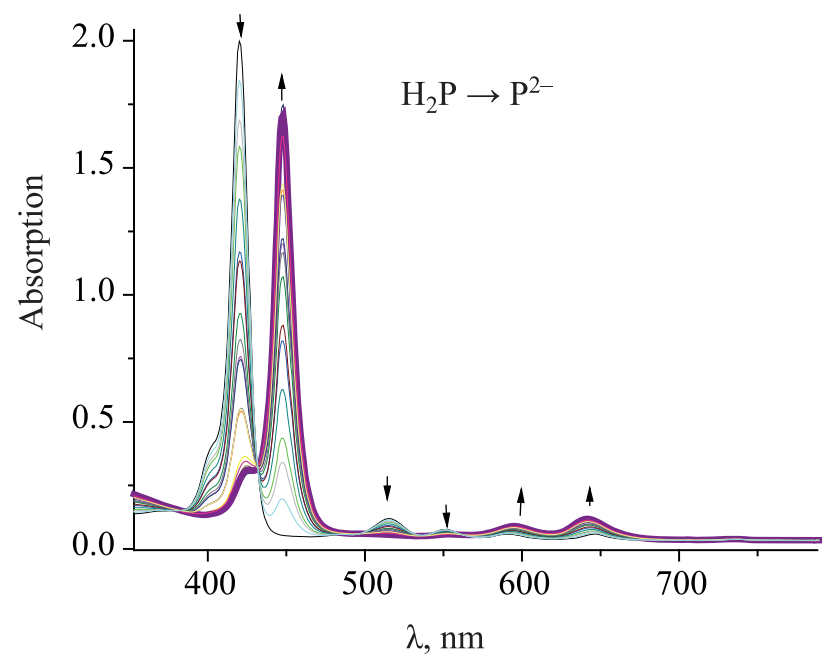

Fig. 6. Change the electronic absorption spectrum of compound $\mathbf{H}_{\mathbf{2}} \mathbf{P} 2$ in DMSO- $\mathrm{KOH}[222]$ system $\left(c_{\text {porph }}=\right.$ $\left.0.83 \times 10^{-5} \mathrm{~mol} / \mathrm{L}, c_{\mathrm{KOH}[222]}=0-5.30 \times 10^{-3} \mathrm{~mol} / \mathrm{L}\right)$ at $298 \mathrm{~K}$.

The electron-donating nature of the solvent in this liquid-phase system leads to the leveling of the ionization constants at the first and second steps, which makes it possible to determine only their total values for porphyrins $\mathbf{H}_{2} \mathbf{P} 1, \mathbf{H}_{2} \mathbf{P 2}, \mathbf{H}_{2} \mathbf{P}$. The leveling effect of solvent must be taken into account when comparing the relative strength of the acidic and basic properties of the molecule, when carrying out reactions, and synthesis of

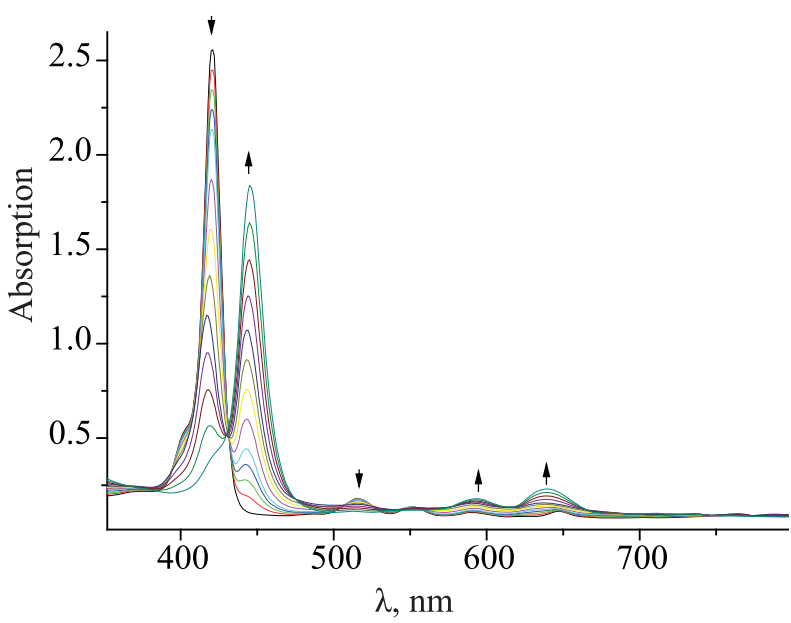

Fig. 7. Change the electronic absorption spectrum of compound $\mathbf{H}_{\mathbf{2}} \mathbf{P 3}$ in DMSO-KOH[222] system $\left(c_{\text {porph }}=\right.$ $\left.1.3 \times 10^{-5} \mathrm{~mol} / \mathrm{L}, c_{\mathrm{KOH}[222]}=0-1.01 \times 10^{-3} \mathrm{~mol} / \mathrm{L}\right)$ at $298 \mathrm{~K}$. 
chemical compounds. Probably, the different dielectric solvents constants (acetonitrile and DMSO), as well as a change in the medium $\mathrm{pH}$, affect the stabilization of the ionic forms of tetraphenylporphyrin derivatives and the leveling of stepwise processes.

\section{EXPERIMENTAL}

The starting compound for obtaining asymmetrical porphyrines $\mathbf{H}_{2} \mathbf{P} 2$ and $\mathbf{H}_{2} \mathbf{P 3}-5$-(4-aminophenyl)10,15,20-triphenyl porphine $\mathbf{H}_{\mathbf{2}} \mathbf{P} \mathbf{1}$ was synthesized in two steps from tetraphenylporphyrin [18]. Solvents (Aldrich, $0.03 \% \mathrm{H}_{2} \mathrm{O}$ ) were used without additional purification.

Electron absorption spectra were recorded on a Cary-100 spectrophotometer (Varian). Mass spectra were registered on a Maldi ToF Shimadzu Biotech Axima Confidence mass spectrometer (matrix-dihydroxybenzoic acid). ${ }^{1} \mathrm{H}$ NMR spectra were recorded on a Bruker Avance $500 \mathrm{MHz}$ spectrophotometer. Acidbase properties were studied with using the procedure presented in the articles $[19,20]$.

\section{5-\{4-[(N-tert-Butoxycarbonyltyrosinyl)amino]-} phenyl $-10,15,20$-triphenylporphine $\left(\mathrm{H}_{2} \mathrm{P} 3\right)$. $253 \mathrm{mg}(0.9 \mathrm{mmol})$ of $\mathrm{N}$-tert-butoxycarbonyltyrosine, $173 \mathrm{mg}$ (0.9 mmol) of 1-(3-dimethylaminopropyl)-3ethylcarbodiimide (EDC) and $50 \mathrm{mg}(0.4 \mathrm{mmol})$ of 4-dimethylaminopyridine (DMAP) were added to $80 \mathrm{~mL}$ of cooled $\left(0^{\circ} \mathrm{C}\right)$ dichlorometane. The reaction mixture was kept at $0^{\circ} \mathrm{C}$ for $1.5 \mathrm{~h}$, then $250 \mathrm{mg}(0.4 \mathrm{mmol})$ of 5-(4-aminophenyl)-10,15,20-triphenylporphine was added to obtained solution. The mixture was stirred for $1 \mathrm{~h}$ at $0^{\circ} \mathrm{C}$, and then $8 \mathrm{~h}$ at room temperature. The reaction product was chromatographed on silica gel eluting at first with dichloromethane, and then with mixture dicholoromethane-methanol, $95: 5$. Yield $161 \mathrm{mg}$ (45\%), $R_{\mathrm{f}} 0.50$ (chloroform-methanol, $95: 5$ ). Electron absorption spectrum $\left(\mathrm{CH}_{3} \mathrm{CN}\right), \lambda_{\max }, \mathrm{nm}$ (log ع): 415 (5.05), 513 (3.89), 548 (3.72), 588 (3.65), 645 (3.63). ${ }^{1} \mathrm{H}$ NMR spectrum $\left(\mathrm{CDCl}_{3}\right), \delta$, ppm: $-2.78 \mathrm{~s}$ $(2 \mathrm{H}, \mathrm{NH}), 1.52 \mathrm{~s}(9 \mathrm{H}, t-\mathrm{Bu}), 3.27-3.00 \mathrm{~m}\left(3 \mathrm{H}, \mathrm{CHCH}_{2}\right)$, $4.60 \mathrm{~s}(1 \mathrm{H}, \mathrm{N} \underline{\mathrm{HCOOBu}}-t), 5.31 \mathrm{~s}(1 \mathrm{H}, \mathrm{PhN} \underline{\mathrm{HCO}}), 6.84 \mathrm{~d}$ [2H, Ph (Tyr), $J=8.5 \mathrm{~Hz}], 7.24 \mathrm{~d}[2 \mathrm{H}, \mathrm{Ph}(\mathrm{Tyr}), J=$ $8.5 \mathrm{~Hz}], 7.61-7.36 \mathrm{~m}(9 \mathrm{H}, \mathrm{Ph}), 7.80 \mathrm{~d}(2 \mathrm{H}, \mathrm{Ph}, J=$ $8.5 \mathrm{~Hz}), 8.07-7.93 \mathrm{~m}(4 \mathrm{H}, \mathrm{Ph}), 8.09 \mathrm{~d}(2 \mathrm{H}, \mathrm{Ph}, J=$ $8.0 \mathrm{~Hz}), 8.15 \mathrm{~d}(2 \mathrm{H}, \mathrm{Ph}, J=8.0 \mathrm{~Hz}), 8.28 \mathrm{~s}[1 \mathrm{H}$, $\mathrm{PhO} \underline{\mathrm{H}}$ (Tyr)], 8.92-8.72 m $(8 \mathrm{H}, \beta-\mathrm{H})$. Mass spectrum (MALDI TOF), $m / z: 894.1847[M+2 \mathrm{H}]^{+}$(calculated for $\mathrm{C}_{58} \mathrm{H}_{48} \mathrm{~N}_{6} \mathrm{O}_{4}$ : 892.3711).
5-[4-(Tyrosinylamino)phenyl]-10,15,20-triphenylporphine $\left(\mathbf{H}_{2} \mathbf{P} 2\right) .50 \mathrm{mg}(0.06 \mathrm{mmol})$ of compound $\mathbf{H}_{2} \mathbf{P} 3$ was dissolved in mixture $2 \mathrm{~mL}$ of dichloromethane and $2 \mathrm{~mL}$ of trifluoroacetic acid. The obtained mixture was kept at room temperature for $4 \mathrm{~h}$. The reaction mass was spilled on crushed ice and neutralized with aqueous solution of ammonia to a slight alkaline reaction. The reaction mixture was extracted with dichloromethane $(3 \times 25 \mathrm{~mL})$. The combined organic extracts were dried under $\mathrm{Na}_{2} \mathrm{SO}_{4}$, solvent was evaporated under vacuum, and the residue was chromatographed on a silica gel, eluentlgemixture dichlorometane-methanol, $95: 5$. Yield $43 \mathrm{mg}(91 \%), R_{\mathrm{f}} 0.37$ (chloroform-methanol, $95: 5)$. Electron absorption spectrum $\left(\mathrm{CH}_{3} \mathrm{CN}\right), \lambda_{\max }, \mathrm{nm}$ (log $\varepsilon): 415$ (5.06), 513 (3.95), 548 (3.82), 591 (3.75), 645 (3.74). ${ }^{1} \mathrm{H}$ NMR spectrum $\left(\mathrm{CDCl}_{3}\right), \delta$, ppm: $-2.78 \mathrm{~s}$ $(2 \mathrm{H}, \mathrm{NH}), 4.36-4.26 \mathrm{~m}\left(3 \mathrm{H}, \mathrm{CHCH}_{2}\right), 4.70$ br. s $(2 \mathrm{H}$, $\mathrm{NH}_{2}$ ), 5.32 br. s (1H, PhNHCO), 7.18-7.09 m [2H, Ph (Tyr)], $7.23 \mathrm{~d}[2 \mathrm{H}, \mathrm{Ph}(\mathrm{Tyr}), J=8.5 \mathrm{~Hz}], 7.57-7.40 \mathrm{~m}$ $(9 \mathrm{H}, \mathrm{Ph}), 7.85 \mathrm{~d}(2 \mathrm{H}, \mathrm{Ph}, J=8.5 \mathrm{~Hz}), 8.01 \mathrm{~d}(2 \mathrm{H}, \mathrm{Ph})$, $8.05 \mathrm{~d}(2 \mathrm{H}, \mathrm{Ph}, J=7.0 \mathrm{~Hz}), 8.10 \mathrm{~d}(2 \mathrm{H}, \mathrm{Ph}, J=8.0 \mathrm{~Hz})$, $8.16 \mathrm{~d}(2 \mathrm{H}, \mathrm{Ph}, J=8.0 \mathrm{~Hz}), 8.48$ br. s [1H, PhOH (Tyr)], $8.90-8.80 \mathrm{~m}(8 \mathrm{H}, \beta-\mathrm{H})$. Mass spectrum (MALDI TOF), $m / z: 794.0587[M+2 \mathrm{H}]^{+}$(calculated for $\mathrm{C}_{53} \mathrm{H}_{40} \mathrm{~N}_{6} \mathrm{O}_{2}$ : 792.3222).

\section{FUNDING}

The study was financially supported by the Russian Foundation for Basic Research (project no. 20-04-60067-Viruses) with using the equipment of the upper Volga region centre of physic-chemical research.

\section{CONFLICT OF INTEREST}

No conflict of interest was declared by the authors.

\section{REFERENCES}

1. Askarov, A.K., Berezin, B.D., and Bystritskaya, E.B., Porfiriny: spektroskopiya, elektrokhimiya, primenenie (Porphyrins: Spectroscopy, Electrochemistry, Application), Moscow: Nauka, 1987.

2. Biesaga, M., Pyrzynska, K., and Trojanowicz, M., Talanta, 2000, vol. 51, p. 209.

https://doi.org/10.1016/S0039-9140(99)00291-X

3. Pylina, Y.I., Startseva, O.M., Rasova, E.E., and Belykh, D.V., Macroheterocycles, 2019, vol. 12, no. 2, p. 165.

https://doi.org/10.6060/mhc181219b

4. Nyman, E.S. and Hynninen, P.H., Photochem. Photobiol. (B), 2004, vol. 73, p. 1.

https://doi.org/10.1016/j.jphotobiol.2003.10.002 
5. Fadda, A.A., El-Mekawy, R.E., and El-Shafei, A.I., J. Porphyr. Phthal., 2015, vol. 19, p. 1. https://doi.org/10.1142/S1088424615500480

6. Kustov, A.V., Kustova, T.V., Berezin, D.B., Belykh, D.V., and Khudyaeva, I.S., Dyes Pigments, 2020, vol. 173, p. 107948. https://doi.org/10.1016/j.dyepig.2019.107948

7. Kruk, M.M., Pukhovskaya, S.G., Ivanova, Yu.B., and Koifman, O.I., Russ. Chem. Bull., 2020, vol. 69, no. 6 , p. 1072. https://doi.org/10.1007/s11172-020-2868-6

8. Senge, M.O., Chem. Commun., 2006, no. 3, p. 243. https://doi.org/10.1039/b511389j

9. Belykh, D.V., Shevchenko, O.G., and Tarabukina, I.S., Macroheterocycles, 2014, vol. 7, no. 1, p. 79. https://doi.org/10.6060/mhc140377b

10. Wang, N., Jiang, S., Du, L., and Shang, J., Front. Microbiol., 2020, vol. 11, p. 298. https://doi.org/10.3389/fmicb.2020.00298

11. Luguya, R., Jaquinod, L., Fronczek, F.R., Vicente, M.G.H., and Smith, K.M., Tetrahedron, 2000, vol. 60, p. 2757. https://doi.org/10.1016/j.tet.2004.01.080

12. Andrianov, V.G. and Malkova, O.V., Macroheterocycles, 2009, vol. 2, p. 130. https://doi.org/10.6060/mhc2009.2.130

13. Sheinin, V.B. and Ivanova, Yu.B., Russ. J. Phys. Chem. (A), 2007, vol. 81, no. 8, p. 1250. https://doi.org/10.1134/S0036024407080134
14. Kolthoff, I.M., Chantooni, M.K., and Sadhana, Ir., Anal. Chem., 1967, vol. 39, no. 13, p. 1627. https://doi.org/10.1021/ac50156a039

15. Pukhovskaya, S.G., Ivanova, Yu.B., Nam, D.T., and Vashurin, A.S., Russ. J. Phys. Chem. (A), 2014, vol. 88, no. 10 , p. 1670. https://doi.org/10.7868/S004445371410032X

16. Dixon, M., MacDonald, A., and White, F., Disorders of Carbohydrate Metabolism, Oxford: Blackwell Sci., 2001, vol. 2, p. 233. https://doi.org/10.1002/9781118915349.ch18

17. Clarce, I.A., Dawson, P.J., Grigg, P., and Pockester, C.H., J. Chem. Soc. Perkin Trans 2, 1973, p. 414. https://doi.org/10.1039/P29730000414

18. Lyubimtsev, A., Semeikin, A., Zheglova, N., Sheinin, V., Kulikova, O., and Syrbu, S., Macroheterocycles, 2018, vol. 11 , no. 1 , p. 103. https://doi.org/10.6060/mhc1711511

19. Ivanova, Yu.B., Churakhina, Yu.I., and Mamardashvili, N.Zh., Russ. J. Gen. Chem., 2008, vol. 78, no. 4, p. 673. https://doi.org/10.1134/S1070363208040269

20. Ivanova, Yu.B., Sheinin, V.B., and Mamardashvili, N.Zh., Russ. J. Gen. Chem., 2007, vol. 77, no. 8, p. 1380. https://doi.org/10.1134/S1070363207080270 